\title{
Developmental and Environmental Responsibilities of the \\ "Rechtsstaat"
}

Prof Dr Joachim Wolf.

Professor for Environmental Law and Administrative Law at the Ruhr-University

Bochum, Germany.

\section{$1 \quad$ Introduction}

Economic development and environmental issues have been linked to and translated into a global conceptual framework at the Rio Conference on the Environment and Development ${ }^{1}$ which was held in 1992. The concept of "sustainable development" is central to this global framework. ${ }^{2}$ When we consider the topic of developmental and environmental responsibilities of the Rechtsstaat we have to focus on "sustainable development" from a national perspective.

\section{Sustainable development: global reconciliation of environmental protection and development}

The conception behind "sustainable development" ${ }^{3}$ could probably be described as the most ambitious and complex goal which has ever been tackled at the level of practical politics and legislation. The goal is to co-ordinate all economic and industrial activities on a world-wide basis to such an extent that the ecological side-effects are tempered and the environmental harm caused by these processes is reduced in order to actively promote sustainable development. ${ }^{4}$ Sustainable development in this sense

1 On the outcome of the Rio Conference see Johnston The Earth Summit.

2 For a discussion on the meaning of this concept, see Beyerlin Sustainable Development; Ginther and De Waart Good Governance 1 ff; Handl Specific Obligations 37 ff; Pallemaerts International Environmental Law 1 ff; Wolf Haftung der Staaten 473, 579 ff.

3 Definition in WCED Our Common Future 43.

4 If one consider the developments in the aftermath of the Rio Conference, definitions which should explain the meaning of the concept "sustainable development" are still of a very general nature. In Brundtland Our common future (report) which provided the conceptual framework for the RioConference, "sustainable development" was defined as "development that meets the needs of the present without compromising the ability of future generations to meet their own needs". This definition relates to human activity in a very general and all-embracing manner. It is an ethical principle which is not based upon a binding legal source or on actual economic relationships. This definition does, however, take cognisance of two aspects which have legal implications. The 
refers to development which is not at the cost of future generations. Article 4 of the Rio Declaration ${ }^{5}$ expresses this ambitious aim in simple words:

In order to achieve sustainable development, environmental protection shall constitute an integral part of the development process and cannot be considered in isolation from it.

\subsection{A common cause for the northern and southern hemisphere}

The outcome of what was decided at the Rio Conference could be summarised by three common causes which were endorsed by all states of both the first and the third world.

Firstly, environmental protection is not only a dilemma of the industrial nations. It is just as much a problem confronting the developing countries. Today governments as well as politicians in both the first and the third world know that a similar or comparable industrialisation of the southern hemisphere on the basis which it took place in the northern hemisphere during the last 150 years is utterly unfeasible. An ecological disaster on a global scale would be unavoidable. To put it differently, the industrialised nations and the developing countries are in the same boat when it comes the twin concept of further economic development and simultaneous environmental protection which is captured by the concept of "sustainable development". 6

Secondly, the economic and ecological aspects relating to the development of a country can no longer be separated. It concerns two sides of the same coin. Today economic policy which does not take ecological aspects into consideration is as unrealistic as it is irresponsible. Similarly, solutions to ecological jeopardy are not possible without due consideration of economic developments. In other words, both

first relates to the fact that the actual effect of industrial activities which cause harm or damage to the environment are legally addressed according to the causative principle (Verursacherprinzip). The second point underscores state responsibility for environmental protection which in principle has been recognised by all states.

5 See Rio Declaration 1992; also in Johnston The Earth Summit 117 ff.

6 The great number of duties to co-operative for environmental protection purposes stipulated by the Rio Declaration is clear evidence of this assessment (see principles 5, 7, 9, 12, 14 and 27). 
the state's economic policy and companies' commercial policies are confronted with a new dimension when it comes to planning and the calculation of costs. ${ }^{7}$

Thirdly, the states participating in the Rio Conference arrived at the conclusion that legal co-operation is required in order to find an acceptable solution to problems relating to development and environmental protection. However, the consequences of the Rio Conference for environmental protection law have not been clarified and are subject to further analysis.

\subsection{The legal consequences of the Rio Conference}

At first sight, the outcome of the Rio Conference for international environmental law appears to be rather insignificant. The Declaration of Rio is not a legally binding document. ${ }^{8}$ Agenda 21 or the "Earth's Action Plan" is also not a document which is legally binding. Moreover, the legally binding Conventions on Climatic Change ${ }^{9}$ and Biological Diversity ${ }^{10}$ only have the character of a legal framework. It is, therefore, of no avail to look for a direct contribution to a solution for environmental protection and development issues on the basis of a Rechtsstaat in any of these documents.

It is nevertheless interesting that the global programme for "sustainable development" is implicitly based on the legal assumption that there is no inconsistency between the prevailing economic system, namely free-market capitalism, and global environmental protection. This deserves attention because the existing economic system is founded upon a monetary structure which depends on constant economic growth. ${ }^{11}$ International free trade, the combat of protectionism, the equalisation of

7 The economic impact of the concept of "sustainable development" has been analysed by Binswanger 1995 ZfU 1-19. His analyses shows that states as well as international organisations nevertheless have little interest in a all-encompassing calculation of costs in the context of sustainable development.

8 Hohmann 1993 NVwZ 311-319.

9 FCCC Climate Change 851.

10 CBD Biological Diversity 818.

11 The possibility of structural conflicts between the capitalistic free market system and the requirements for effective international environmental protection are also barely addressed in the economic field - see the informative study of Binswanger 1995 ZfU 4. Binswanger 1995 ZfU 6 pays special attention to the issues related to monetary policies which depend on constant economic growth. See Schreiber Umweltprobleme for a discussion of the effects of socialistic economic systems on the environment. 
agricultural products and industrial goods in the GATT as well as in the law relating to the WTO, global transport relations, open markets for the production and consumption of energy and the aim to keep down costs of energy and transport are secured on a global basis by means of multilateral as well as bilateral agreements. It is not surprising, therefore, that the basic premises of free market capitalism is endorsed unqualifiedly by Principle 12 of the Rio Declaration in order to secure sustainable development:

States should co-operate to promote a supportive and open international economic system that would lead to economic growth and sustainable development in all countries, to better address the problems of environmental degradation. Trade policy measures for environmental purposes should not constitute a means of arbitrary or unjustifiable discrimination or a disguised restriction on international trade. Unilateral actions to deal with environmental challenges outside the jurisdiction of the importing country should be avoided. Environmental measures addressing transboundary or global environmental problems should, as far as possible, be based on an international consensus.

No state represented at the Rio Conference critically addressed the issue whether the effects of this economic system on the environment are compatible with the principles of a Rechtsstaat. ${ }^{12}$ It was more a question of the industrial nations and the developing countries being unanimous on the issue that problems relating to global environmental

12 This approach is contrary to the practical politics of all the countries which are significant in a economic sense. The programme of multilateral action and environmental protection measures which are based on the consensus of every member state are often not observed anymore when a state is of the opinion that it is exposed to by an environmental risk with which it can deal effectively on an unilateral basis. From the perspective of the Rechtsstaat principle, no objection can be made to such an approach. According to the norms of the Rechtsstaat, the only requirement is that competent state organs should act in accordance with national law. Collective measures in terms of international law only enjoy precedence over real risks of damage only under circumstances when such measures do in fact exist and are just as effective as measures in terms of national law. Very often these requirements are not fulfilled. In such a case, multilateral action and multilateral consensus remains a mere postulate. With regard to unilateral state measures for environmental protection which are in conformity with the Rechtsstaat principle, international economic law has an uncovered flank. How difficult it is to close such an uncovered flank, has been well illustrated by the history background of art XX GATT (1947). Fifty years after the adoption of this agreement this important exception relating to the legal system of 
degradation could only be resolved technologically on the basis of the existing economic system. The key to this is to be found in the concept of the "transfer of technology" from the industrialised countries to the developing countries. ${ }^{13}$ This idea unifies both aspects of the global environmental protection, namely environmental protection by means of the technique of avoiding further degradation of the environment and the decrease of disparities in standards of living between North and South by economic development. In other words, the message coming from the Rio Conference clearly has economic overtones.

\section{The level of state implementation}

With regard to the central issue of balancing economic development with environmental protection, the legal implementation of sustainable development is in the hands of the individual state governments. Only the state governments are endowed with the powers of statutory and economic sovereignty which form the legal basis for effectively promoting sustainable development.

Legislatures on a national level are of great significance when it comes to formulating and executing responsibilities associated with a Rechtsstaat. Since there are certain modifications to the basic framework of the implementing economic and environmental law in the European Union, ${ }^{14}$ I suggest that we focus on the law of the Federal Republic of Germany and European law binding Germany with regard to the responsibility of a Rechtsstaat for sustainable development.

international trade law has not been very much clarified - in this regard, compare Walker Environmental Protection.

13 Art 9 of the Rio Declaration; Beyerlin and Ehrmann 1997 Umwelt- und Planungsrecht 356-361.

14 For an exposition on European environmental law, see Frenz Europäisches Umweltrecht 1-75 and Epiney Europäischen Union 1-3. 
Which challenges confront the Rechtsstaat when we focus on economic development which should also be acceptable from an environmental point of view? This inquiry causes unresolved difficulties for three reasons.

Firstly, the concept of the Rechtsstaat has not yet been clarified in all its dimensions. We usually list the various components which are integral to this concept: the guarantee of human rights, the separation of state powers and effective legal protection. ${ }^{15}$ However, we seldomly address the nature (or Wesen) of the Rechtsstaat as such. ${ }^{16}$ A comparison of the British concept of the "rule of law" which departs from the premises that the executive is bound by Parliamentary legislation, ${ }^{17}$ on the one hand, and the German constitutional state, resting upon the foundation that legislation should be in conformity with the norms of the Constitution and controlled by the (German) Federal Constitutional Court, also does not reveal much about the nature of the Rechtsstaat. ${ }^{18}$

The second difficulty concerns economic development. Especially in a Rechtsstaat which presupposes an economic system free from state interference, the relationship between the state and economic life has not been clarified. ${ }^{19}$ Generally applicable rules pertaining to the conditions and the degree of state interference which might be acceptable to regulate the economy do not exist. ${ }^{20}$ The constitutional limits to such

15 BVerfG 7, 89 (92 f); BVerfG 65, 283 (290). See also Ipsen Staatsorganisationsrecht Rn 648 ff. For an extended list of the various elements of the Rechtsstaat, see Sachs Grundgesetz Kommentar art 20 Rn 77, 78. See also Lerche Übermaß und Verfassung 32.

16 The thorough study of Kunig Rechtsstaatsprinzip $312 \mathrm{ff}$ is an exception to the rule. Kunig analyses the being-a-Rechtsstaat of the Federal Republic of Germany according to the Constitution. He rightly does not endorse an "abstract" notion of the concept of the Rechtsstaat.

17 On the historic development of the rule of law in England, see Taswell-Langmead English Constitutional History 350 ff; Maitland Constitutional History of England 270 ff; Blackstone Laws of England 160; Dicey Law of the Constitution 39.

18 See Blaau 1990 SALJ 88 ff; Neumann Rule of Law $182 \mathrm{ff}$.

19 The expositions on the economic system (Wirtschaftsverfassung) of the Federal Republic of Germany by Schmidt Öffentliches Wirtschaftsrecht $\S 3$ at 65 ff; Stober Wirtschaftsverwaltungsrecht $\S 5$ at $63 \mathrm{ff}$ and Weimar and Schimikowski Wirtschaftsrechts $13 \mathrm{ff}$ have the following in common, namely that no constitutional proscription of a specific economic system exists and that the constitutional basis for commercial activity and the limits thereof are to be found in the fundamental rights.

20 In art 109 s 2 GG, the German Constitution sets the standard for budgetary policies of the federation and the Länder that they should take due cognisance of the "requirements of [a] macro- 
regulation, ${ }^{21}$ should it be possible to define them, are often in opposition to political expectations for stimulating the economy. The higher the unemployment levels, the more intense becomes the pressure on the state to create jobs and to interfere in the free market system. Environmental protection could therefore easily be misused as the basis for allowing the state to directly manipulate economic processes.

The third difficulty is related to environmental protection and environmental law. Not only the legal boundaries to state interference in economic processes have not been clearly drawn. Even the inquiry why environmental law developed as a new branch of law and what it is that distinguishes it from other fields of law very much remain in the dark. There are often no clear answers to the dilemma of finding a justification for environmentally motivated measures which affect economic freedom of individuals.

It is therefore no easy challenge for a legal scholar to clarify how a Rechtsstaat could effectively facilitate sustainable development. In a certain sense, one feels like the mathematician who tries to add up noughts to get the sum total of one.

\subsection{Rechtsstaat}

The Rechtsstaat is characterised by the fact that it is composed of various elements which stand in a specific relationship to the law through which the principles are

economic equilibrium" (ie the "Erfordernissen des gesamtwirtschaftlichen Gleichgewichts"). In contrast to the fundamental rights which regulate state competencies in a negative sense, requiring organs of state authority to refrain from unjustifiably encroaching upon these rights and freedoms, this standard is directed at positive state action with regard to financial planning, obliging state organs to act in a specific manner. The contents of this planning goal has not been defined at a constitutional level. Art 1 of the Budgetary Stability Act specifies four criteria for these purposes, viz stability of the level of prices, a high level of employment, a foreign-trade equilibrium and constant economic growth. Although these criteria are in principle not subject to critique, they have not contributed to clarify the constitutional basis of the economic system nor did they lead to the legal tightening of the criteria which enable state interference in commercial activities. It seems, therefore, that these criteria are unsuitable to contribute to resolving the potentially explosive relationship between state responsibility for economic development on the one hand, and environmental protection, on the other.

21 BVerfGE 81, 70-97 (85), (decision of the Federal Constitutional Court of 14.11.1981); Hufen 1994 Neue Juristische Wochenschrift 2915; Tettinger Art 12 GG Rn 179. 
expressed. A Rechtsstaat is a state which is bound by law and justice both with regard to the manner in which it is structured and how it acts through its organs. ${ }^{22}$

The Rechtsstaat is often distinguished by the fact that there is a separation of the powers vested with state authority. However, the emphasis is on the legal structure which guarantees that the separation of powers forms part of the Rechtsstaat concept. The legislative power is separated from the executive and the judiciary, and as next step, the executive again from the judiciary. This separation of powers constitutes more than a mere formal requirement for a legal order based on the Rechtsstaat. It is a prerequisite for the binding force of law and justice. It is also an imperative that the Rechtsstaat can only "act" through the decisions taken by the executive and the courts. The exercise of legislative powers is not part of governmental action and should it be attributed to the governmental powers, the separation of powers and the basis of the Rechtsstaat itself would no longer be secured. In other words, should this happen, the Rechtsstaat would be perverted to an all encompassing executive power. ${ }^{23}$

The decisive question is: what is justice in terms of the Rechtsstaat? What are the general rules or "laws" of justice in a Rechtsstaat? As a first step the laws of justice have to be distinguished from the sum of existing parliamentary statutes. The statutes made by Parliament are only an attempt to formulate the general norms of justice for a specific state. The Rechtsstaat, though, departs from the ideal that the statutes which are adopted by Parliament should conform with generally accepted norms of justice. ${ }^{24}$ Let me illustrate the point with three examples:

- If the state tolerates crime and no longer exercises policing powers to prevent it or to prosecute crimes, the state is at risk to loose control over those areas where life is dictated by crime. Furthermore, the state will have to accept that the threatened population living in that area will negate the prohibition of the use of

22 See Stern Staatsrecht 781. In terms of the Constitution, the Rechtsstaat consists of the following: the fundamental rights directly binding all branches of state power (art $1 \mathrm{~s} 3 \mathrm{GG}$ ), the separation of powers (art 20 s 2 GG), the legality of administrative action as well as the binding force of law with regard to adjudication (art 20 s 3 GG). This constitutional order is the warranty of the Rechtsstaat system.

23 Stern Staatsrecht 786; Eichenberger Gesetzgebung im Rechtsstaat 40 ff, 68 ff.

24 Schmidt-Assmann Rechtsstaat § $24 \mathrm{Rn} 4$. 
force in social conflicts and the corresponding state monopoly to solve social conflicts by using force to protect themselves.

- Should the state allow that the working population and consumers are commercially exploited by monopolies and uncontrolled competition of companies, the consequence will be that at a certain stage the closed-circuit commercial system will collapse. The confidence and trust of investors will disappear and they will be unwilling to risk their capital for new investments. Consequently the commercial basis of ordinary people is destroyed and simultaneously also their ability to consume products.

- Similarly, when a state does not take precautionary measures to protect the environment and natural living conditions of human life, then it will be too late one day. In this context, the precautionary rule has become a kind of "basic law for environmental protection". This rule for environmental protection is different in its nature from other norms of justice relating to human life such as the prohibition of using force, including the prohibition of unjust enrichment. The legal responsibility with regard to environmental conservation is existential in the most basic sense. It is a prerequisite for life. Once the environment and natural living conditions in a state have been destroyed, only one solution remains: to leave the country, or more extremely, to flee from it.

All these examples relate to basic conditions of justice. Should these norms of justice be transgressed, the bill with the consequences will inevitably be presented to us one day. We not only risk an increase of legal conflict, but chaos. We know today that chaos is also governed by predetermined patterns: it is determined by the rules of survival of the fittest and chance or coincidence. Life according to the rules of chaos is the exact opposite of life according to the rules of justice. ${ }^{25}$

To a large extent the degree of the environmental degradation with which we are confronted today can be traced back to the false belief of lawyers that the norms of

25 On the characteristic of law as a mechanism to create order, see Schmidt-Assmann Rechtsstaat § 24 Rn 21; Stern Staatsrecht 767. 
justice can be isolated from the rules of natural sciences relating to physics, chemistry and biology. ${ }^{26}$ The time has come that the jurisprudential basis of our law, including the norms of the Rechtsstaat, should take more cognisance of the law of nature. In other words, if a statute permits dangerous emissions which do not only lead to a temporary nuisance but to permanent ecological harm, this is contrary to the rules of justice which is one of the cornerstones of the Rechtsstaat. Such a statutory provision does not preclude ecological harm but in fact forms the legal basis for continued and increasing environmental degradation. It would seem, therefore, that a more integrated approach to master the legal problems related to environmental protection is the proper point of departure for this evolving field of law called "environmental law".

\subsection{Environmental protection as a duty of the state}

Environmental law encompasses all legal sources which aim at controlling the technological and industrial civilisation in order to secure our natural living conditions. ${ }^{27}$ Environmental law is not restricted to statutory law and administrative regulations which have been created since environmental protection became popular. $^{28}$ Insofar as existing sources of law permit activities which are counterproductive to environmental protection and endanger our natural living conditions,

26 Every general law, be it in the form of parliamentary statutes or laws of nature (ie the laws of natural sciences), depends on causal effects which the human being can recognise but which he cannot change. The statutes of a state which are adopted by a legislature constitute a special category of such laws. These statutes are adopted by Parliament for a specific state and only find application within the sphere of its territorial and personal jurisdiction. The inherent conflict between statutes and the laws of nature is nowhere better illustrated than in the case of environmental law. Should the legislature adopt parliamentary legislation for environmental protection which ignores or negates the laws of nature (ie in physics, chemistry and biology), these statutes have no long-term perspective. At one or other stage the legislation will have to be amended, eg when the critical level which is set for regulating the drinking water quality is too low, nature will not recover sufficiently and the level will inevitably have to be adapted in due course. In other words, the belief that a state legislature could make generally applicable laws for all people by only taking its own perspectives and aims into account, does not correspond to reality. If this misconception is not corrected, the Rechtsstaat will not be able to fulfil its obligations with regard to environmental protection.

27 Hoppe and Beckmann Umweltrecht 23; Oberrath Umweltrecht 17.

28 This misunderstanding stems from the unquestioned definition of environmental law in Germany as a new and independent field of law. According to this definition, environmental law encompasses all legal regulations which serve environmental protection. Kloepfer Umweltrecht $\S$ 1 Rn 60 defines environmental law as "Sonderrecht der staatlichen Umweltschutzaktivitäten". Such a teleological definition is too restrictive in its conception. It does not explain the complexity of the planning and regulatory character of environmental law. 
they also fall within the scope of environmental law. Logically the amendment of such legislation also forms part of environmental protection law. ${ }^{29}$

Taking the state of affairs with regard to the current developments on an economic and technological level into account, the responsibility for environmental protection predominantly rests upon the state. $^{30}$ The state not only has to create the legal basis for future economic and technological developments which are compatible with environmental protection, but also has the duty to regulate environmental harm which has already occurred. ${ }^{31}$ In other words, the state has the duty to invoke measures which could help to neutralise such harm or to clean up or redevelop an area where an environmental disaster took place. On closer examination, though, the true responsibility for environmental protection is not only directed at the state. ${ }^{32}$ Everybody who is in a position to cause harm to the environment carries the responsibility for it.

\subsection{Challenges to the "Rechtsstaat" with regard to "sustainable development"}

The most important difficulty facing a Rechtsstaat when it comes to the realisation of "sustainable development" lies in the structural differences between the constitutional order based on the Rechtsstaat idea, on the one hand, and the dynamics of political and economic planning, on the other.

The basic structure of economic law in a free market system with constitutionally guaranteed rights of private persons is characterised by freedom from state

29 See Kimminich Umweltschutzes 12.

30 A more restrictive approach is endorsed by Kloepfer Umweltrecht § 1 Rn 24.

31 See the Directive on Environmental Policy of the federal government which was adopted in 1971 and is still applicable, BT Drs VI/2710.

32 The reason for concentrating on environmental responsibility as forming part of the state's duties in both German environmental law and the first three environmental programmes of the European Council until the end of the 1980's can be historically and systematically explained. From a historic perspective, the state is held environmentally responsible due to the fact that it over many years neglected the ecological harm stemming from industrialisation and economic development. From a systematic point of view, the reasons can be found in the changing relationship of the state vis-á-vis economic life. The greater the extent to which economic development is regulated in terms of statutes and administrative regulations, the more environmental law also becomes subject to state regulation although environmental protection is no longer based only on historic neglect. 
interference. $^{33}$ In principle legislative measures and administrative regulations are restricted to providing a legal basis and ensuring a proper infrastructure for economic and social intercourse without regulating commercial activities as such. The planning of trade policy measures by the state is subject to the constraints of the fundamental rights guaranteeing free commercial activity. ${ }^{34}$ A limitation of these rights may be justified under specific circumstances, for example when the measures serve innovative technological developments which are to the advantage of the whole economy. On an all-over basis, however, commercial freedom takes precedence over planning policy.

In environmental law the tables are turned: the relationship between legally guaranteed freedom and the realisation of planning policy goals with the aid of regulations is often reversed. In this instance, planning law is more predominant. ${ }^{35}$ The reason for this is that only measures falling within the scope of planning law are suitable to generally reduce environmental pollution which already occurred or to promote new technology which offers an environmentally friendly alternative.

From the perspective of the Rechtsstaat concept, environmental problems can only be resolved with the aid of environmental-law measures. The political goal to protect the environment often falls flat because there is no statutory basis authorising the state to regulate economic development. However, with a too extensive regulation of economic and technological development, the Rechtsstaat would fail in its responsibility ${ }^{36}$ in a similar manner as it would when it follows an absolute laissezfaire policy with regard to such developments. The challenge for the Rechtsstaat is to determine the most suitable legal measures which are indispensable to steer and

33 According to arts 2 and 3 of the EC Treaty, the economic order of the EC is directed at the creation of a market where individual freedoms are guaranteed to all participants in the market, especially with regard to the free movement of goods under conditions of fair competition compare the decision of the European Court of Justice, of 19.03.1991, I ECR 1223, 1269 par 41 about telecommunication devices. Due to the fact that European law enjoys precedence, the free market economic system is binding for all member states. Therefore, the open-ended manner in which the German Constitution treats the economic system has no real implications for matters relating to the Common Market.

34 Hufen 1994 Neue Juristische Wochenschrift 2915; Tettinger Art 12 GG Rn 180.

35 Kloepfer Umweltrecht § 5 Rn 5; Erbguth Rechtssystematische Grundfragen 124; Hoppe and Beckmann Umweltrecht $\S 7$ Rn 1 ff.

36 BVerfG 50, 290-381, (338), (decision of the Federal Constitutional Court of 01.03.1979). See also Breuer Freiheit des Berufs § 147 Rn 20. 
control economic activities in order to prevent environmental degradation. These duties of the state can best be highlighted with a few comments on the Rechtsstaat, economic freedom and environmental law:

- In order to influence commercial activities and consumer attitudes, a clear distinction should legally be drawn between consumer goods which could be increased and regenerated and other goods which cannot. The latter should be classified as public or environmental goods. ${ }^{37}$ In the absence of such a distinction, neither indispensable natural resources can be protected with longterm environmental measures, nor can the precise scope of economic activity which is affected be determined.

- Due to the fact that natural resources are becoming more depleted environmental law is increasingly also understood as a mechanism serving the ends of fair distribution of these natural resources (that is distributive justice). ${ }^{38}$ Potential conflicts between the developmental responsibility and the environmental responsibility of the Rechtsstaat cannot be resolved without prior clarification what the concepts "distribution" and "scarcity" mean in a legal context. Currently we can only quote economic explanations. The economic premises departs from the assumption that there is no private ownership of natural resources and that market-related prices for natural resources cannot be determined. It is controversial whether it is possible for the state to substitute market-related prices for natural resources by charging environmentally related fees for utilising these resources. ${ }^{39}$ This discussion shows that the traditional distinction between economic goods and services, on the one hand, and natural resources, on the other, is still appropriate and valid in both a legal and an economic sense. It also sets limits to legal measures for the development of distributive procedures.

37 See Kloepfer and Reinert Umweltfragen $41 \mathrm{ff}$.

38 Gethmann, Kloepfer and Reinert Verteilungsgerechtigkeit (fn 37).

39 Kloepfer and Reinert Umweltfragen 43, 45 (fn 37). 
- Existing private and criminal law regulations should not be restricted or weakened only because they apparently impede economic and technological development. Especially restrictions to private property and the administrative treatment of jeopardy to people's health as a general risk of life should still be subject to control on a legal basis. In other words, economic and technologicals development have to adapt to the rules of private and criminal law and not vice versa. $^{40}$

- $\quad$ Should there be uncertainty about the ecological risks related to technical plants and dangerous substances, the planned commercial utilisation should be subject to prior administrative scrutiny. ${ }^{41}$ Three issues should be clarified during such an examination. First, does the uncertainty with regard to the risk lead to an unlawful hazardous risk when one carefully consider the degree of the risk ${ }^{42}$ Secondly, is the risk connected with the utilisation - which otherwise would have been legally inadmissible - mitigated by technical and other precautionary measures to such an extent that the risk connected with such a utilisation is reduced insofar that it becomes legally admissible? Thirdly, should the second inquiry be answered positively, which criteria should be invoked to determine the scope of the precautionary measures and who should carry the costs of it?

\section{Possible solutions at a constitutional level}

During the mid-1980's a debate ensued whether environmental protection should be guaranteed in the Constitutional. Finally, in 1994, article 20a GG have been inserted

40 In the Civil Code (BGB) the law dealing with the law of neighbours the diametric opposite line has been endorsed. According to a statutory amendment of 1994 (BGBl I 2457), German civil law regulating the level of emissions opted for the opposite approach. In terms of § 906(1) BGB took the public-law critical values stipulated by the Federal Emissions Control Act and other environmental laws as a basis.

41 Compare the licensing procedure in terms of the Nuclear Plant Act § 7; compare also the requirements with regard to the Environmental Impact Assessment (EC Directive 85/337); Environmental Impact Assessment Act (UVPG).

42 The boundaries of illegality relating to risk without causing damage have not been clearly defined. So, eg, a violation of fundamental rights is assumed in the case of a mere risk when the highest possible standards with regard to the operation of a nuclear power station are not upheld compare the decision of the Federal Constitutional Court in the Kalkar matter (BVerfG 49, 89 ff). In contrast, the standards are not that strict when it comes to gene-technological research. 
in the Constitution (Grundgesetz) which formally stipulates environmental protection as a goal of the state.

Since the adoption of the Uniform European Act, environmental protection measures found their way into the European Community Treaty ${ }^{43}$ as well. These measures have twice been extended and intensified - both in the Maastricht and the Amsterdam Treaties. However, none of these measures directly contribute to resolve the dilemma of environmental protection confronting a Rechtsstaat with regard to technological and industrial development and the dictates of constant economic growth.

\subsection{No environmental fundamental right}

The German constitutional amendment of 1994 deliberately did not take up environmental protection in the catalogue of fundamental rights. During the preceding debate such a fundamental right on healthy environmental sources for everybody has often been demanded though. ${ }^{44}$ Should Parliament have taken this way, the legal protection for individuals in environmental-law cases would have been improved to a large extent. Those who were against the incorporation of a fundamental right to a clean environment in the Constitution were afraid of leaving it to the courts to resolve conflicts on environmental protection and economic development. Because no consensus could be reached on the exact contents of such a fundamental right its listing in the bill of rights has been thwarted. ${ }^{45}$

It is also not to be expected that a fundamental right guaranteeing a clean environment will be adopted in European law in the near future because a written catalogue of fundamental rights has not been incorporated in the European Union Treaty.

Should such a fundamental right in fact have been incorporated in the German Constitution, the most important obstacle which currently stands in the way of effective constitutional protection of the natural sources for living would have been

43 Art 130(r-t) EC Treaty.

44 Steiger Mensch und Umwelt $62 \mathrm{ff}, 73 \mathrm{ff}$; see also Kloepfer Grundrecht auf Umweltschutz; for further references also Kloepfer Umweltrecht § 3 Rn 21 (fn 62 and 63).

45 See the exposition by Peters 1995 NVwZ 555 and Henneke 1995 NuR 325. 
eliminated. Legal protection would have been guaranteed without requiring the individual to first prove a causal connection with the concrete harm to his/her health in a specific instance. ${ }^{46}$ In the case of a fundamental right guaranteeing the "natural sources of life", it would have been sufficient merely to establish that ecological damage took place in the vicinity where the plaintiff lives. The state would no longer have been in a position to justify the limitation of the most general fundamental right in terms of the German Constitution, namely the right to general personal freedom (article 2 section 1 GG) on the basis of economic considerations.

\subsection{Article 20a as a state goal of environmental protection}

In terms of German constitutional law, state goals (Staatsziele) bind the legislature and should be translated into legislation. Article 20a GG which formulates environmental protection as a "state goal" reads as follows:

The State, aware of its responsibility for present and future generations, shall protect the natural [re]sources of life within the framework of the constitutional order through the legislature and, in accordance with the law and principles of justice, the executive and the judiciary. ${ }^{47}$

As in the case of the constitutional goal of establishing a welfare state (Sozialstaat) ${ }^{48}$, the goal to "protect the natural sources of life" has been formulated in very general terms. In principle, the legislature is only required to present a concept for a legislative programme to protect the environment. ${ }^{49}$ There are no legal sanctions available to enforce it. Even the constitutional criteria to determine whether a "state goal" is thwarted have not been clarified with any agreed certainty. ${ }^{50}$

46 Brönneke 1993 Zeitschrift für Umweltrecht 1.

47 The original German text is as follows: "Der Staat schützt auch in Verantwortung für die künftigen Generationen die natürlichen Lebensgrundlagen im Rahmen der verfassungsmäßigen Ordnung durch die Gesetzgebung und nach Maßgabe von Gesetz und Recht durch die vollziehende Gewalt und die Rechtsprechung." The German concept of "Lebensgrundlagen" has been translated with "natural sources of life" in the official translation. "Resources" would perhaps have been a more appropriate translation to capture the spirit of the concept.

48 In terms of art 20 s 1 GG.

49 Bernsdorff 1997 NuR 332; Schink 1997 DÖV 323.

50 Some academics argue that art 20a GG at the very least constitute a general prohibition of a deterioration of the environmental status quo. The guarantee of the status quo of the environment 
The object and purpose of such a state goal to protect the environment is to create a constitutional framework which ensures that all essential developments in regard to environmental protection, including those areas which overlap with economic development, remain subject to legislative incentives and regulation. The fact that the German legislature is bound to respect fundamental rights does not really create any limitations which are worth mentioning when it comes to environmental protection. ${ }^{51}$ This was also clear from the debate whether or not to incorporate such a fundamental right in the Bill of Rights.

However, as long as the legal protection of individuals relating to environmental-law issues is not put on a proper legal footing, the sensitive area of economic development in this field which is central to such disputes cannot be influenced by the courts. This is particularly true with regard to harmful or dangerous emissions which pollute the air, water and soil. From a legal perspective, such emissions constitute a legal risk (Rechtsgefährdung) but cannot be classified as a concrete statutory transgression (Rechtsverletzung). ${ }^{52}$ In other words, because such harmful and dangerous emissions create a legal risk (Risikoverursachung) without causing damage (Schadensverursachung), legal protection of environmental sources fall between two stools. ${ }^{53}$

\subsection{Open-ended constitutional programme}

In essence it is impossible to provide an answer to the inquiry on the nature of the relationship between economic development and environmental protection at a constitutional level. The constitutions of all the countries which endorse the concept of the Organisation for Economic Co-operation and Development (OECD) show one similarity, namely not any generally applicable rules exist with regard to the influence

would then have a constitutional basis, see eg Kloepfer Bonner Kommentar Rn 35 ff. However, should the environmental standards deteriorate, it is not clear what the legal consequences are. Experts, however, are indeed expecting such a deterioration of the environment.

51 Murswiek Kommentierung zu Art 20a GG Rn 56; Kloepfer Umweltrecht § 3 Rn 56.

52 Regarding exceptions in cases of extremely high risks, e.g. the use of nuclear energy, see footnote 42 above.

53 Murswiek Kommentierung zu Art 20a GG Rn 63. 
which may be exercised by any of these states on their economy. Not even the extent of state participation in providing services or the number of state enterprises participating in the economy has been legally restricted. To put it differently, the state's economic policy has deliberately not been made subject to any constitutional constraints with regard to its contents.

For the same reason there are no generally binding limitations to the realisation of the state's environmental protection. $^{54}$ The constitutions of the OECD countries deliberately does not set specific limits to the degree of admissible pollution or the extent to which environmental risks are permitted because this would have a detrimental effect on the open-ended manner in which the constitutions treat economic policy making.

Critically considered this was also the gist of the debate on extending the German Bill of Rights to include a fundamental right for the protection of environmental freedom. In a certain sense the state goals which are formulated by article 20a GG resemble the playing of table tennis. The protection of the natural sources of life is stipulated explicitly in the Constitution in order to improve environmental protection but at the same time the ball is returned to the legislature. In other words, the constitutional protection of the environmental is back in the hands of the legislature, leaving it a free hand with regard to the kind of legislation it may adopt to reach this goal.

\section{Precautionary principle}

On an all-over basis it seems fair to suggest that the most important contribution to get to grips with the responsibilities of the Rechtsstaat in promoting environmental protection has been made by legislative bodies in European as well as in German environmental law. The legislative measures require that precautionary measures should be taken by those who cause the environmental damage or risk. ${ }^{55}$ Such

54 Murswiek Kommentierung zu Art 20a GG Rn 60.

55 Compare Federal Emissions Control Act (BimSchG) §§ 1, 5 I nr 1, 2 and the Federal Water Resources Act § 1(a). 
statutory measures are increasingly invoked and form the basis for an emerging new legal principle, namely the precautionary principle. ${ }^{56}$

According to article 130(r) of the EC Treaty,

... community policy on the environment shall ... be based on the precautionary principle and on the principle that preventive action should be taken.

The distinction between precautionary principle and mere preventive action was introduced by the Maastricht Treaty in 1992. Legal protection prior to the new regulation in terms of the Maastricht Treaty placed the emphasis on mere preventive action. Consequently, it appears that the recently introduced precautionary principle has been intended as a regulation in its own right and with a legal impact distinct from the rule simply emphasising preventative action.

Mere preventive action refers to the protection of public security, including the protection of everybody's rights under circumstances where concrete a danger exists. ${ }^{57}$ Such a "concrete" danger is required to be of an immediate nature in the sense that an infringement of rights or a violation of the laws will definitely occur if the danger is not averted. Such protective and preventive measures are normally taken by the police force. In this regard, the police authorities act in a twofold manner according to principles of the Rechtsstaat. Firstly, the action of the police force serves the protection of law and freedom and in effect this constitutes the most important instrument for safeguarding public security. Secondly, the powers of the police force to take preventive action, including their discretionary powers to infringe upon the rights and freedoms of those who destroy or endanger public security, are restricted to situations of concrete and imminent danger. The assessment whether a "concrete" danger does exist under specific circumstances depends upon the general experience and on specific information held by the authorities. The discretionary power of the police force in deciding whether a concrete danger exists is therefore subject to strict

56 Lersner Vorsorgeprinzip $2703 \mathrm{ff}$.

57 On the law of hazard prevention, see Di Fabio Risikoentscheidungen $35 \mathrm{ff}$. 
scrutiny by the courts. The usual manifestation of a concrete danger with which the police authorities is confronted differs in two important respects from risks that are covered by environmental protection law though:

1. The risk potential of certain kinds of technology (for example nuclear energy plants and biotechnology) or of specific substances (for example cancerogenic materials) is too high to be controlled only in terms of the standards invoked by police authorities.

2. With regard to this higher level of risk potential, the legal standard for preventive measures is modified from a standard aimed at the prevention of damages to a standard which is directed at the prevention of risks. In legal terms this has far-reaching consequences: the requirement that a probability of damage exists is replaced by the possibility of danger of damage. This latter condition is referred to as a "risk". Risk in this context does not refer to a risk in a vague sense of danger that might result but to a specific legal meaning which is attached to it. ${ }^{58}$ The precautionary principle addresses the problem of safety standards and their implementation with regard to the risk of accidents in technical plants with unacceptable environmental consequences. The main problem concerning the implementation of the precautionary rule is to find a key for attributing the costs for technical equipment to reduce dangerous emissions to either the plant operator, the state or both of them.

Apart from preventing environmental accidents the authorities who are authorised to license and control technical plants also have to tackle the problem of reducing day to day emissions into the air, watercourses and the soil. A single car driver's carbon dioxide emissions, for example, hardly cause an environmental risk. But all car drivers together do cause a considerable environmental problem. If you add technical plants and technical equipment in private households which produce similar air pollutants it escalates to such an extent that the scales are tipped towards the extremely serious problem of climatic changes. The ways and methods invoked by legislatures to master these problems on the basis of the precautionary principle are 
very different in nature. We shall focus on two approaches, that is the procedural approach and the approach of setting specific technical standards.

\subsection{Procedural approach}

Directives of European Community law treat the precautionary principle as a procedural approach. The most important contribution in European law in this regard is the Directive on the Environmental Impact Assessment. ${ }^{59}$ All direct and indirect effects of a planned undertaking must be established for purposes of an environmental impact assessment. The effects are described in a detailed manner and are subsequently assessed. In essence the procedure aims at preventing and reducing all potential risks and harm to the environment already at the stage before an operating license is issued.

However, a central difficulty which has not been addressed and not yet solved by this procedure is that of defining specific precautionary standards. It has been left to administrative practice to develop such standards.

\subsection{The approach of technical standards in terms of the precautionary principle under German law}

In terms of German law, the most important precautionary regulation can be found in the Air Pollution Act of 1974. The Act stipulates that the owner of a technical plant is under the obligation to take precautionary measures to prevent environmental harm with the aid of instruments or mechanisms which correspond to the advanced techniques available for the limitation of such polluting emissions. This provision is intended to solve the precautionary problem in a material sense by regulating the specific risk of a single plant in relationship to a given technical standard to prevent

emissions. It is not only possible but is day to day administrative practice in Germany to lay down specific technical standards for the reduction of dangerous and harmful emissions. Should a plant owner be unable to fulfil his obligations with regard to the 
implementation of the specified precautionary standard, the legal consequences are obvious, namely that the authority may not issue him with an operating license.

However, there are two difficulties in existing precautionary legislation which cannot be disregarded. First, the key problem remains that we are not yet in a position to legally relate a specific amount of emissions which is dangerous or detrimental to the environment with a specific number of precautionary measures which are necessary in terms of the precautionary principle to avoid environmental harm. ${ }^{60}$ In essence it boils down to the following: instead of the amount of precautionary measures we could just as well speak of the costs related to the implementation of precautionary measures without changing the legal problem.

Secondly, with regard to the issue of cost distribution there is no other option available in administrative practice for the time being than to apply well-known general formula, namely the test of reasonableness and the principle of proportionality. In contrast to the traditional application of these rules and formula, the facts of environmental disputes are often not all that clear-cut. This is due to the typical factor of uncertainty associated with environmental risks and jeopardy. In the context of the precautionary principle, therefore, the test of reasonableness and the proportionality rule cannot be applied in the usual way. This dilemma has not been resolved in German environmental law and is still debated. ${ }^{61}$

\section{Environmental quality standards}

A similar legal basis than the precautionary principle in environmental law does not exist with regard to state responsibility for economic development. Compared to economic development, the law relating to environmental protection is not of a regulatory but of a planning-law nature. This is illustrated very well by the

59 UVP-RL 85/337/EWG. This directive was belatedly transformed into national legislation in Germany by the Environmental Impact Assessment Act of 12 February 1990.

60 Ossenbühl Kernkraftwerken 54; Di Fabio 1996 Jura 572 f.

61 See Di Fabio 1996 Jura 574 for further references. 
environmental quality standards which found their way into German law via European law. ${ }^{62}$

The aim of environmental quality standards is to enable the legislature, government or expert commissions to determine a specific emission standard for a certain field of environmental protection by means of binding planning directives or in the form of a programme which ensures an acceptable quality standard. An example of such a quality standard is that local authorities may determine whether water is clean enough for swimming purposes. The prerequisite is that the water may not contain any detrimental pollutants which could cause harm to people in one or other way. Another quality standard is the aim to reduce harmful emissions into the air by half at a specific future date or to prohibit the emission of specific substances altogether. Even the goal to maintain the status quo with the aim that a specific level of emissions should not further deteriorate constitutes a quality standard.

The legal flexibility of planning law distinguishes these environmental quality standards from other regulatory measures. At the stage of formulating the quality standards, the initial economic premises as well as the long-term economic goals can be taken into account. ${ }^{63}$ The realisation of such quality goals are just as flexible. It can take on the form of a legally binding goal, a political programme with a specific aim or a goal set on the basis of scientific or expert knowledge. Lately specific industries often take the initiative themselves to participate in orderly market agreements with regard to quality standards for environmental protection, sometimes even in the form of unilateral self-binding declarations. This form of quality standard realisation has gained in importance. However, it is controversial whether such declarations are of a legally binding nature and whether they are suitable to relieve the state from its responsibility for environmental matters.

Should the industry indeed meet these orderly market agreements or unilateral declarations with regard to quality standards, they could contribute substantially to effectively improve environmental protection. What is of importance for the relation

62 For a discussion, see BUND Sachstandsbericht; SRU Umweltgutachten $129 \mathrm{ff}$. 
between environmental protection and economic development is that the costs due to environmental quality standards are not only calculated by the state but also by those causing environmental harm on the basis of the quality goals they voluntarily set for themselves.

\section{Conclusion}

To conclude, the responsibility of the Rechtsstaat has not been defined in an acceptable manner, neither with regard to its responsibility for environmental protection nor with regard to its responsibility for sustainable development. This is a characteristic feature of economic development based on high technology and which is based upon legislative or socio-political decisions to a great extent. In a freemarket system which is based upon fundamental rights of participants in economic life, the relation of the state's responsibility for environmental protection, on the one hand, and economic development, on the other, can be summarised with the following remarks:

- We should analyse disputes which constitute an environmental risk on the basis of existing national law as well as European Community law, treating it as a closely interrelated legal network. All provisions and rules which may contribute to solve the environmental risk in legal terms should be taken into account. If such an analysis would lead to the conclusion that the detrimental consequences in the case of environmental damage exceed the possibilities of legal restitution the hazardous activity should be regarded as unlawful. It is the responsibility of the Rechtsstaat to address the problem of environmental risks and potential damages according to the precautionary principle.

- A comparable responsibility of the Rechtsstaat for economic development in such a general and encompassing sense does not exist. This is due to the fact that each state takes decisions about its economic system in a sovereign manner and shapes the economic, employment and social welfare legislation to fit its

63 Fürst ea Umweltqualitätsziele. For a critical evaluation of loopholes to abuse the quality standards, see Lübbe 1996 Zeitschrift für Umweltrecht 64. 
national requirements. However, a prerequisite for the economic system of a Rechtsstaat is that state interference in the economic life - despite national economic interests - is always subject to the fundamental rights of those who participate in commerce.

- An irrefutable interrelationship exits between environmental protection and economic development in state politics. In order to give effect to the precautionary principle, the state already has to scrutinise the environmental impact of its economic policy at the stage of planning it. In other words, the precautionary principle not only has a regulatory character but also a planninglaw dimension. ${ }^{64}$ Thus one can no longer distinguish between economic planning and environmental planning which is subject to the precautionary principle in a Rechtsstaat.

64 In terms of European environmental law, the environmental impact assessment should also apply with regard to local and state planning law - see EC Directive 85/337. 


\section{BIBLIOGRAPHY}

Bernsdorff 1997 NuR 332

Bernsdorff $N$ "Positivierung des Umweltschutzes im Grundgesetz (Art 20a GG)" $1997 \mathrm{NuR}$ 328-334

Beyerlin and Ehrmann 1997 Umwelt- und Planungsrecht 356-361

Beyerlin U and Ehrmann M "Fünf Jahre nach dem Erdgipfel von Rio" 1997 Umwelt- und Planungsrecht 356-361

Beyerlin Sustainable Development $95 \mathrm{ff}$

Beyerlin U "The Concept of Sustainable Development" in Wolfrum R (ed) Enforcing Environmental Standards: Economic Mechanisms as Viable Means? (Springer Berlin 1996) 640

Binswanger 1995 ZfU 1-19

Binswanger $\mathrm{M}$ "Sustainable Development: Utopie in einer wachsenden Wirtschaft?" 1995 ZfU 1-19

Blaau 1990 SALJ 88 ff

Blaau LC "The Rechtsstaat Idea Compared with the Rule of Law as a Paradigm for Protecting Rights" 1990 SALJ 76-96

Blackstone Laws of England 160

Blackstone W Commentaries on the Laws of England (Cadell London 1765) vol I 485

Breuer Freiheit des Berufs § 147 Rn 20 
Breuer R "Freiheit des Berufs" in Isensee J and Kirchhof P (eds) Handbuch des Staatsrechts der Bundesrepublik Deutschland (Müller Verlag Heidelberg 1987) 1279

Brönneke 1993 Zeitschrift für Umweltrecht 1

Brönneke T "Vom Nutzen einer einklagbaren Umweltverfassungsnorm" 1993 Zeitschrift für Umweltrecht 1

Brundtland Our common future

Brundtland GH (World Commission on Environment and Development) Our common future Reprint (University Press Oxford 1989) 400

BUND Sachstandsbericht

Bund für Umwelt und Naturschutz Deutschland (ed) Sachstandsbericht: Studie zukunftsfähiges Deutschland (1994)

CBD Biological Diversity 818

CBD Convention on Biological Diversity of 5 June 199231 ILM

Di Fabio 1996 Jura 572 ff

Di Fabio U "Gefahr, Vorsorge, Risiko" 1996 Jura 572

Di Fabio Risikoentscheidungen $35 \mathrm{ff}$

Di Fabio U Risikoentscheidungen im Rechtsstaat: zum Wandel der Dogmatik im öffentlichen Recht, insbesondere am Beispiel der Arzneimittelüberwachung (Mohr Tübingen 1994) 515

Dicey Law of the Constitution 39 
Dicey AV Introduction to the Study of the Law of the Constitution 10th ed (MacMillan London 1959)

Eichenberger Gesetzgebung im Rechtsstaat $40 \mathrm{ff} 68 \mathrm{ff}$

Eichenberger K "Gesetzgebung im Rechtsstaat: Berichte und Diskussionen auf der Tagung der Vereinigung der Deutschen Staatsrechtslehrer in Trier vom 30. September - 3. Oktober 1981" in Eichenberger K Novak R and Kloepfer M Veröffentlichungen der Vereinigung der deutschen Staatsrechtslehrer (De Gruyter Berlin 1982) 355

Epiney Europäischen Union 1-3

Epiney A Umweltrecht in der Europäischen Union: [primärrechtliche Grundlagen; gemeinschafliches sekundärrecht] (Heyman Köln 1997) Part I

Erbguth Rechtssystematische Grundfragen 124

Erbguth W Rechtssystematische Grundfragen des Umweltrechts (Duncker und Humblot Berlin 1987) 452

FCCC Climate Change 851

FCCC (UN) Framework Convention on Climate Change of 15 May 1992 A/AC 237/18 (Part II)/Add1 31 ILM

Frenz Europäisches Umweltrecht 1-75

Frenz W Europäisches Umweltrecht (Beck München 1997) 292

Fürst ea Umweltqualitätsziele

Fürst D ea Umweltqualitätsziele für die ökologische Planung (1992) 
Gethmann Kloepfer and Reinert Verteilungsgerechtigkeit

Gethmann CF Kloepfer M and Reinert S (eds) Verteilungsgerechtigkeit im Umweltstaat (Economica-Verlag Bonn 1995) 85

Ginter and De Waart Good Governance $1 \mathrm{ff}$

Ginther K and De Waart PJIM "Sustainable Development as a Matter of Good Governance: An Introductory View" in Ginther K ea (eds) Sustainable Development and Good Governance (Nijhoff Dordrecht 1995) 483

Handl Specific Obligations $37 \mathrm{ff}$

Handl G "Sustainable Development: General Rules versus Specific Obligations" in Lang W (ed) Sustainable Development and International Law (Graham and Trotman London 1995) 319

Henneke 1995 NuR 325

Henneke H-G "Der Schutz der natürlichen Lebensgrundlagen in Art 20a GG: inhalt und Wirkungen einer ausbalancierten Staatszielbestimmung" $1995 \mathrm{NuR}$ 325-335

Hohmann 1993 NVwZ 311-319

Hohmann H "Ergebnisse des Erdgipfels von Rio" 1993 NVwZ 311-319

Hoppe and Beckmann Umweltrecht 23

Hoppe W and Beckmann M Umweltrecht: juristisches Kurzlehrbuch für Studium und Praxis (Beck München 1989) 579

Hufen 1994 Neue Juristische Wochenschrift 2915 
Hufen F "Berufsfreiheit - Erinnerung an ein Grundrecht" 1994 Neue Juristische Wochenschrift 2913-2922

Ipsen Staatsorganisationsrecht Rn 648 ff

Ipsen J Staatsrecht I (Staatsorganisationsrecht) 10th ed (Luchterhand Neuwied 1998)

Johnston The Earth Summit $117 \mathrm{ff}$

Johnston D The Earth Summit (1994)

Kimminich Umweltschutzes 12

Kimminich O Das Recht des Umweltschutzes 2nd ed (Goldmann München 1974)

Kloepfer Bonner Kommentar Rn 35 ff

Kloepfer M in Bonner Kommentar Art 20a GG Rn 35 ff

Kloepfer Grundrecht auf Umweltschutz

Kloepfer M Zum Grundrecht auf Umweltschutz: Vortrag gehalten vor der

Berliner Juristischen Gesellschaft am 18. Januar 1978 (De Gruyter Berlin 1978) 40

Kloepfer Umweltrecht

Kloepfer M Umweltrecht 2nd ed (Beck München 1998) 1416

Kloepfer and Reinert Umweltfragen $41 \mathrm{ff}$ 
Kloepfer $\mathrm{M}$ and Reinert $\mathrm{S}$ "Umweltfragen als Verteilungsprobleme in rechtlicher Sicht" in Gethmann CF Kloepfer $\mathrm{M}$ and Reinert $\mathrm{S}$ (eds) Verteilungsgerechtigkeit im Umweltstaat (Economica-Verlag Bonn 1995) 85

Kunig Rechtsstaatsprinzip 312 ff

Kunig P Das Rechtsstaatsprinzip: Überlegungen zu seiner Bedeutung für das Verfassungsrecht der Bundesrepublik Deutschland (Mohr Tübingen 1986) 524

Lerche Übermaß und Verfassung 32

Lerche P Übermaß und Verfassung: zur Bindung des Gesetzgebers an die Grundsätze der Verhältnismäßigkeit und der Erforderlichkeit (Köln Heymann 1961) 361

Lersner Vorsorgeprinzip $2703 \mathrm{ff}$

Lersner V "Vorsorgeprinzip" in Kimminich O (ed) Handwörterbuch des Umweltrechts: HdUR 2nd ed (Erich Schmidt Berlin 1994) 2868

Lübbe 1996 Zeitschrift für Umweltrecht 64

Lübbe A "Umweltindikatoren: Instrumente einer nachhaltigen Umweltpolitik?" 1996 Zeitschrift für Umweltrecht 64

Maitland Constitutional History of England $270 \mathrm{ff}$

Maitland FW The Constitutional History of England: a course of lectures (University Press Cambridge 1908) 547

Murswiek Kommentierung zu Art 20a GG Rn 56 ff

Murswiek D "Kommentierung zu Art 20a GG" in Sachs M (ed) Grundgesetz Kommentar (Beck München 1996) 2015 
Neumann Rule of Law $182 \mathrm{ff}$

Neumann FL The Rule of Law - Political Theory and the Legal System in Modern Society (Berg Leamington Spa 1986) 349

Oberrath 1996 Umweltrecht 17

Oberrath JD 1996 Umweltrecht 17

Ossenbühl Kernkraftwerken 54 f

Ossenbühl F Bestandsschutz und Nachrüstung von Kernkraftwerken (Heymann Köln 1994) 140

Pallemaerts International Environmental Law $1 \mathrm{ff}$

Pallemaerts M "International Environmental Law from Stockholm to Rio: Back to the Future?" in Sands P (ed) Greening International Law: politics of international environmental law (Earthscan Publications London 1993) 260

Peters 1995 NVwZ 555

Peters HJ "Art 20a - Die neue Staatszielbestimmung des Grundgesetzes" 1995 $N V w Z 555$

Rio Declaration 1992

Distr General A/Conf 151/5/Rev1 13.06.1992 ILM 31876

Sachs (ed) Grundgesetz Kommentar

Sachs M (ed) Grundgesetz: Kommentar 2nd ed (Beck München 1999) 2311 
Schink 1997 DÖV 323

Schink A "Umweltschutz als Staatsziel" 1997 DÖV 321-329

Schmidt Öffentliches Wirtschaftsrecht $65 \mathrm{ff}$

Schmidt R Öffentliches Wirtschaftsrecht (Springer Berlin 1990) 553

Schmidt-Assmann Rechtsstaat § 24

Schmidt-Assmann E "Der Rechtsstaat" in Isensee $\mathrm{J}$ and Kirchhof $\mathrm{P}$ (eds) Handbuch des Staatsrechts der Bundesrepublik Deutschland (Müller Verlag Heidelberg 1987) 1279

Schreiber Umweltprobleme

Schreiber H Umweltprobleme in Mittel- und Osteuropa (Campus Frankfurt 1989) 280

SRU Umweltgutachten $129 \mathrm{ff}$

Der Rat von Sachverständigen für Umweltfragen Umweltgutachten (1994)

Steiger Mensch und Umwelt $62 \mathrm{ff}$

Steiger $\mathrm{H}$ Mensch und Umwelt: zur Frage der Einführung eine Umweltgrundrechts (Schmidt Berlin 1975) 93

Stern Staatsrecht $767 \mathrm{ff}$

Stern K Das Staatsrecht der Bundesrepublik Deutschland: Grundbegriffe und Grundlagen des Staatsrechts, Strukturprinzipien der Verfassung 2nd ed (Beck München 1984) 1110 
Stober Wirtschaftsverwaltungsrecht $63 \mathrm{ff}$

Stober R Wirtschaftsverwaltungsrecht 10th ed (Kohlhammer Stuttgart 1996) 458

Taswell-Langmead English Constitutional History $350 \mathrm{ff}$

Plucknett TFT [English Constitutional History] From the Teutonic Conquest to the Present Time 11th ed (Sweet and Maxwell London 1960) 733

Tettinger Art 12 GG Rn 179-180

Tettinger PJ "Art 12" in Sachs M (ed) Grundgesetz: Kommentar 2nd ed (Beck München 1999) 2311

Walker Environmental Protection

Walker SL Environmental Protection Versus Trade Liberalization: finding the balance; an examination of the legality of environmental regulation under international trade law regimes (Publ des Fac Univ Saint-Louis Bruxelles 1993) 193

Weimar and Schimikowski Wirtschaftsrechts $13 \mathrm{ff}$

Weimar R and Schimikowski P Grundzüge des Wirtschaftsrechts 2nd ed (Vahlen München 1993)

Wolf Haftung der Staaten $473 \mathrm{ff} 579 \mathrm{ff}$

Wolf J Die Haftung der Staaten für Privatpersonen nach Völkerrecht (Duncker und Humblot Berlin 1997) 817

WCED Our Common Future 43 
World Commission on Environment and Development Our Common Future (1987)

\section{Statutes}

Air Pollution Act of 1974

Budgetary Stability Act (Stabilitätsgesetz) of 1967 (BGBl I 582)

EC Directive 85/337

EC Directive 85/337 of 27.06.1985 Environmental Impact Assessment EC Gazette of 05.07.1985 nr L 175/40

Environmental Impact Assessment Act (Gesetz über die Umweltverträglichkeitsprüfung) of 1990 (BGBl I 205) (BGBl III 2129-2120)

Federal Emissions Control Act (Bundes-Immissionsschutzgesetz) (BGBl I 721) (BGBl I 880)

Federal Water Resources Act (Wasserhaushaltsgesetz) (BGBl I 1529) (BGBl I 1695)

Nuclear Plant Act (Atomgesetz) (BGBl I 3053) (BGBl I 1565)

UVP-RL 85/337/EWG

UVP-RL 85/337/EWG Richtlinie des Rates über die Umweltverträglichkeitsprüfung bei bestimmten öffentlichen und privaten Projekten Official Gazette L 175/40 


\section{Cases}

BVerfG 7, 89 (92 f)

BVerfG 65, 283 (290)

European Court of Justice of 19.03.1991 I ECR 1223, 1269

Federal Constitutional Court of 01.03.1979 (BVerfG 50, 290-381, (338))

Federal Constitutional Court in the Kalkar matter (BVerfG 49, 89 ff)

Federal Constitutional Court of 14.11.1981 (BVerfGE 81, 70-97 (85))

$\begin{array}{ll}\text { ABBREVIATIONS } \\ \text { Art(s) } & \text { - Article(s) } \\ \text { art(s) } & \text { - article(s) } \\ \text { BImSchG } & \text { - Bundes-Immissionsschutzgesetz } \\ \text { BT-Drs } & \text { - Bundestags-Drucksache } \\ \text { BverfG } & \text { - Bundesverfassungsgericht } \\ \text { f } & \text { - and the following page } \\ \text { ff } & \text { - and the following pages } \\ \text { fn } & \text { - footnote } \\ \text { NuR } & \text { - Natur und Recht } \\ \text { NVwZ } & \text { - Neue Zeitschrift für Verwaltungsrecht } \\ \text { OECD } & \text { - Organisation for Economic Co-operation and Development } \\ \text { Rn } & \text { - Randnummer(s) } \\ \text { S } & \text { - Section } \\ \text { s } & \text { - section } \\ \text { UVPG } & \text { Gesetz über die Umweltverträglichkeitsprüfung }\end{array}$


WCED - World Commission on Environment and Development

ZfU - Zeitschrift für Umweltpolitik und Umweltrecht 